\title{
Lessons learned from functional assessment of pluripotency-associated transcription factors during early embryogenesis and embryonic stem cells
}

\author{
[Lições obtidas a partir de avaliações funcionais de fatores de transcrição relacionados à \\ pluripotência durante a embriogênese inicial e em células-tronco embrionárias]
}

\section{"Revisão/Review"}

\section{Priscila Germany Corrêa da Silva ${ }^{1}$, Marcelo Tigre Moura ${ }^{1 *}$, Ludymila Furtado Cantanhêde ${ }^{1}$, José Carlos Ferreira-Silva ${ }^{1}$, Pábola Santos Nascimento ${ }^{1}$, Roberta Lane de Oliveira Silva ${ }^{2}$, José Pompeu dos Santos Filho ${ }^{3}$, Marcos Antonio Lemos Oliveira ${ }^{1}$}

\author{
${ }^{1}$ Laboratório de Biotécnicas Reprodutivas, Universidade Federal Rural de Pernambuco, Recife-PE, Brasil. \\ ${ }^{2}$ Laboratório de Genética e Biotecnologia Vegetal, Universidade Federal de Pernambuco, Recife-PE, Brasil. \\ ${ }^{3}$ Departamento de Biologia, Universidade Federal Rural de Pernambuco, Recife-PE, Brasil. \\ *Autor para correspondência/Corresponding author: E-mail: marcelotmoura@gmail.com
}

\begin{abstract}
Pluripotency-associated transcription factors (PATF) play significant roles during early embryogenesis and in embryonic stem (ES) cells, such as control of cell-cycle progression, modulation of cellular metabolism, and transcriptional control of differentiation-inducing factors. The review aims to describe the current understanding of how these PATFs contribute to the early embryo and the ES-cell phenotypes. By a selection of representative examples of such PATFs, their roles are described, and some interesting questions are presented concerning their activity in pluripotent cells which have yet to be addressed.
\end{abstract}

Keywords: embryology; pluripotent; preimplantation development; totipotency.

\section{Resumo}

Fatores de transcrição relacionados à pluripotência (FTRP) apresentam importantes funções durante a embriogênese inicial e em células-tronco embrionárias (CTE), como o controle da progressão do ciclo celular, modulação do metabolismo celular e controle transcricional de fatores indutores de diferenciação celular. O objetivo da revisão foi descrever o conhecimento vigente sobre como estes FTRPs contribuem para o fenótipo dos embriões e CTEs. Através da seleção de exemplos representativos destes FTRPs, suas funções são descritas e algumas perguntas interessantes são apresentadas considerando suas atividades em células pluripotentes, mas que ainda não foram devidamente respondidas.

Palavras-Chave: embriologia; pluripotente; desenvolvimento pré-implantacional; totipotência.

\section{Introduction}

Early embryogenesis in mammals can be defined as the period of development before implantation (Rossant, 2007; Cockburn and Rossant, 2010; Wu et al., 2017). After the process of fertilization and egg activation, DNA replication is initiated in both haploid genomes, followed by syngamy of pro-nuclei and the first mitotic division, thus forming the two-cell stage embryo (Rossant, 2007; Wu et al., 2017). Moreover, the embryo goes through several rounds of cell divisions, denominated cleavages, that ultimately lead to a progressive reduction in blastomere volume (Figure 1). During this period of embryonic development, blastomeres remain relatively similar in shape, and have limited adhesion among them. There is no transcription in the early embryo and its developmental coordination and timing are determined by maternal factors found in the egg (Latham, 1999; Wu et al., 2017). Therefore, such cleavage divisions are rather fast in timing, with short G1 and G2 phases during the cell cycle (Frankenberg et al., 2016; Wu et al., 2017).

After a variable number of cell divisions (i.e., 2-cell stage in mice, 8-16 cell transition in 
ruminants), embryos go through the embryonic genome activation (EGA) (Memili and First, 2000). EGA activates the genes of the embryo that progressively dominate the transcriptional output of embryonic cells (Latham, 1999; Wu et al., 2017). When the EGA is concluded, the embryo faces a period of compactation (Frankenberg et al., 2016). At this stage, outer cells carry out a morphological change and acquire an epithelial- like morphology, in contrast to the spherical shape of inner cells in the embryo (Cockburn and Rossant, 2010; Wu et al., 2017). This difference in blastomere morphology becomes more evident at the morula stage (Figure 1), alongside with transcriptional variations are observed in these two different cell types (Rossant, 2016; Wu et al., 2017).

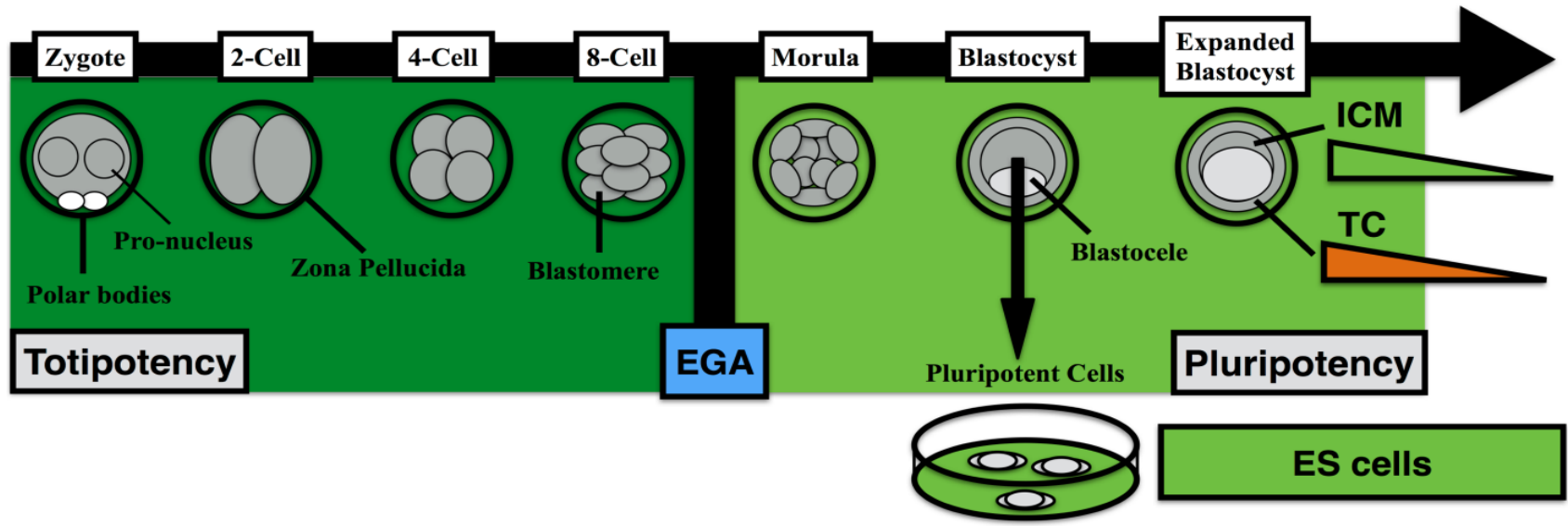

Figure 1. Developmental potential of early embryos and embryonic stem cells. Totipotency is limited to early cleavage-stage embryos before embryonic genome activation (EGA) (dark green). After blastocyst formation, the inner cell mass (ICM) progressively exits pluripotency toward the three embryonic germ layers (light green). Trophectoderm cells (TC) gradually differentiates into placenta-forming cell types (Orange). Alternatively, a stable pluripotency state is captured by establishment and propagation of ICM-derived embryonic stem (ES) cells.

At a discrete portion of the embryo, liquid begins to accumulate, leading to blastocele formation. The expansion of the blastocele occurs in parallel to the process of cellular differentiation that is culminated at the blastocyst stage (Figure 1), with the segregation between the inner cell mass and trophectoderm (Rossant, 2007; Wu et al., 2017). There are significant differences in embryo morphology among mammalian species (Frankenberg et al., 2016), although their functional properties remain similar.

The process of cellular differentiation that was initiated during the compactation period is closed with the formation of the blastocyst (Cockburn and Rossant, 2010; Wu et al., 2017). The outer cells of the blastocyst make the trophectoderm, thus carrying an epithelial-like morphology and give the three-dimensional structure of the blastocyst. The inner cell mass (ICM) is composed of round cells aggregated in a three-dimensional structure and adhered to the trophectoderm. More importantly, these morphological changes are accompanied by contrasting functional and developmental potency abilities (Wu et al., 2017). The trophectoderm gives rise to all cell types that make up the placenta, while the ICM has the potential to form all cell types that make up the fetus (Cockburn and Rossant, 2010; Rossant, 2016).

\section{Totipotency}

The tremendous developmental capacity of early embryos has been the focus of intense experimentation since the XIX century (Tagarelli et al., 2004). Initial studies relied on amphibian embryos, which are relatively large, easy to culture in simple solutions, have considerable size compared to their mammalian counterparts, and are more resistant to experimental manipulation (Gurdon, 2006). The mechanical isolation of two blastomeres in a frog embryo resulted in the formation of two tadpoles, thus proving that such cells retain the capacity to give rise to the whole organism (Tagarelli et al., 2004). Similar experiments were carried out with mammalian embryos up to the eight-cell stage (Moore, 1968; Willadsen, 1981), leading to the understanding that this developmental potency, denominated 
totipotency, is also retained in such embryos. Thus, totipotency is defined as the capacity to derive all cell types that make up the fetus and the placenta (Rossant, 2016). Remarkably, no cell type retains the totipotency state after the EGA.

\section{Pluripotency}

The pluripotent state is defined as the capacity of a cell to differentiate into all tissues of the three germ layers, namely endoderm, mesoderm, and ectoderm. Pluripotent cells display high nuclear to cytoplasm ratio, multiple nucleoli, relatively short cell cycles, among other distinctive features (Smith, 2001). The ICM differentiates into the epiblast and hypoblast, that will form the fetus and amniotic sac, respectively (Cockburn and Rossant, 2010; Rossant, 2016). The epiblast cells also give rise to primordial germ cells (PGC) (McLaren, 2000), that migrate to gonadal ridges and form the germ cells lineages (Barton et al., 2016).

The introduction of ICM pluripotent cells into recipient embryos demonstrates that these cells contribute to the formation of mots, if not all, tissues in the fetus (Nagy et al., 1990; Picard et al., 1990). By using modified embryos that progressively contribute exclusively to placenta formation, the introduction of pluripotent cells allows the formation of viable fetuses (Nagy et al., 1990).

The isolation and in vitro culture of the ICM under defined conditions allow the establishment of cultures of pluripotent cells coined as embryonic stem (ES) cells (Evans and Kaufman, 1981; Smith, 2001; Buehr et al., 2008; Li et al., 2008). These ES cells maintain a typical morphology and can be propagated indefinitely in culture (Smith, 2001; Moura, 2012). When exposed to differentiationinducing factors, such as growth factors and cytokines, they exit the pluripotent state and differentiate into multiple cell types both in vitro and in vivo (Smith, 2001). Moreover, when subject to appropriate differentiation cues, ES cells are capable of forming relatively homogeneous populations of discrete cell types, such as motor neurons or cardiomyocytes (Smith, 2001; Wernig et al., 2007; Ichida et al., 2014).

The introduction of ES cells in recipient embryos results in the formation of fetuses with contribution of cells of both origins (Bradley et al., 1984). Moreover, since ES cells are pluripotent, they require a recipient embryo for the placenta formation (Nagy et al., 1990; Eggan et al., 2002).
Collectively, these in vivo functional assays demonstrate the pluripotent nature of ES cells.

\section{Unraveling the control of totipotency and pluripotency}

The investigation at the molecular level of pluripotency in early embryos holds several challenges, such as fast developmental kinetics, transcription-independent development during cleavage stages, cellular differentiation in a relatively short period, and limited stating biological material for experimentation (Hochedlinger and Jaenisch, 2006; Moura, 2012). Due to these factors, most investigations on pluripotency control relies on ES cells, thus contributing to a fast-paced understanding of the mechanism (Hochedlinger and Jaenisch, 2006; Moura, 2012). In humans, ES cells require different culture conditions compared to mouse counterparts to sustain pluripotency and self-renewal (Amit et al., 2000; Chen et al., 2015).

The genetic ablation of a gene contributes to the determination of its functions since cell phenotype lacking the factor can be readily observed (Capecchi, 1989, 2005). By the identification of genes required for pluripotency, their characterization began to increase (Nichols et al., 1998; Niwa et al., 2000; Chambers et al., 2003; Dejosez et al., 2008).

The genes required for the maintenance of pluripotency or that play central roles in this cellular state are collectively called pluripotency genes ( $\mathrm{Li}$ and Belmonte, 2017). Initially, pluripotency genes were identified as those with expression restricted to pluripotent or totipotent cells, namely germ cells, oocytes, early embryos, and ES cells (Schöler et al., 1989; Chambers et al., 2003; Mitsui et al., 2003). With the increasing number of pluripotency genes characterized (Heng et al., 2010), it became evident that few of such genes indeed have a pluripotency-specific gene expression profile.

The number of pluripotency genes characterized continues to grow and thus seems to be relatively far from saturation (Subramanian et al., 2009; Zheng and Hu, 2014). Therefore, the mechanisms by which pluripotency genes control this cellular state is expected to grow in players and complexity in the foreseeable future. This understanding should contribute to better understanding of the mechanisms of totipotency, pluripotency, embryonic development, and selfrenewal of ES cells. The dissection of how each 
pluripotency gene contributes to the pluripotency controlled at the molecular level (Table 1). state has shed light on how this cellular state is

Table 1. Requirement of selected pluripotency-associated transcription factors in early preimplantation embryos and embryonic stem cells.

\begin{tabular}{|c|c|c|c|c|c|}
\hline Gene & $\begin{array}{l}\text { Required for } \\
\text { Blastocyst } \\
\text { Development }\end{array}$ & $\begin{array}{l}\text { Required for } \\
\text { ES Pluripotency }\end{array}$ & Organism & $\begin{array}{l}\text { Observations of null or } \\
\text { knockdown phenotypes }\end{array}$ & References \\
\hline C-MYC & No & No & Mouse & $\begin{array}{l}\text { Redundancy with L-MYC S } \\
\text { and N-MYC, while sole } \\
\text { ablation of C-MYC causes } \\
\text { lower proliferation }\end{array}$ & \\
\hline DAX1 & No & Yes & Mouse & $\begin{array}{c}\text { Impaired testis } \\
\text { development and } \\
\text { male infertility in mice }\end{array}$ & $\begin{array}{l}\text { Yu et al.., 1998; } \\
\text { Niakan et al., } 2006\end{array}$ \\
\hline GLIS1 & Yes & Not Reported & Cattle & $\begin{array}{l}\text { Development arrest at the } \\
\text { 4-cell stage in cattle }\end{array}$ & Takahashi et al., 2015 \\
\hline KLF5 & No & $\mathrm{No}^{*}$ & Mouse & $\begin{array}{l}\text { KLF2, KLF4, and KLF5 } \\
\text { redundancy in ES cells*; } \\
\text { Embryonic loss before } \\
\text { E6.5 in mice }\end{array}$ & Ema et al., 2008 \\
\hline NANOG & No & Yes & Mouse & $\begin{array}{l}\text { NANOG-deficient ICM } \\
\text { fail to generate epiblast }\end{array}$ & $\begin{array}{l}\text { Chambers et al., 2003; } \\
\text { Mitsui et al., } 2003\end{array}$ \\
\hline OCT4 & $\begin{array}{l}\mathrm{No}^{\# ;} \\
\text { Yes }\end{array}$ & Yes & $\begin{array}{l}\text { Mouse, Cattle, } \\
\text { Pig, and } \\
\text { Human }\end{array}$ & $\begin{array}{l}\text { ICM is not pluripotent in } \\
\text { the mouse }\end{array}$ & $\begin{array}{l}\text { Nichols et al., 1998; } \\
\text { Kwon et al., 2015; } \\
\text { Sakurai et al., 2016; } \\
\text { Fogarty et al., 2017 }\end{array}$ \\
\hline RONIN & No & Yes & Mouse & $\begin{array}{c}\text { Embryonic loss at E7.5 } \\
\text { in mice }\end{array}$ & Dejosez et al., 2008 \\
\hline SOX2 & No, Yes & Yes & $\begin{array}{l}\text { Mouse and } \\
\text { Cattle }\end{array}$ & $\begin{array}{c}\text { One intact cell in a two- } \\
\text { cell bovine embryo rescues } \\
\text { development }\end{array}$ & $\begin{array}{l}\text { Avilion et al., 2003; } \\
\text { Gossis and Cibelli, 2014; } \\
\text { Sakurai et al., } 2016\end{array}$ \\
\hline ZFP281 & Unknown & Variable** & Mouse & $\begin{array}{l}\text { Possible confounding } \\
\text { effect of knockdown assay } \\
\text { or culture conditions } * *\end{array}$ & $\begin{array}{l}\text { Wang et al., } 2006 ; \\
\text { Fidalgo et al., } 2011\end{array}$ \\
\hline ZFX & No & No, Yes & $\begin{array}{l}\text { Mouse and } \\
\text { Human }\end{array}$ & $\begin{array}{l}\text { Full-term development, } \\
\text { but smaller, less viable } \\
\text { and diminished pool } \\
\text { of germ cells }\end{array}$ & Luoh et al., 1997 \\
\hline
\end{tabular}

ICM: inner cell mass. E6.5-7.5: 6.5 and 7.5 embryonic days post-coitus, respectively.

\section{Pluripotency-Associated Transcription Factors}

Genes characterized for pluripotency control are predominantly composed of transcription factors, thus pluripotency-associated transcription factors (PATF) (Young, 2011; Yeo and Ng, 2013). These PATFs act on gene regulation, by inducing or silencing target genes. Several PATFs are required for the establishment of cellular states, acting as sole factors, but more frequently in an orchestrated manner to control. dozens or hundreds of downstream target genes (Boyer et al., 2005; Kim et al., 2008; Young, 2011).

A new striking demonstration of the importance of pluripotency genes was demonstrated by the cellular reprogramming of mouse and human somatic cells with their ectopic expression (Takahashi and Yamanaka, 2006, 2016; Takahashi et al., 2007). These induced pluripotent stem (iPS) cells, closely resemble and are functionally similar to embryo-derived ES cells (Maherali et al., 2007; Okita et al., 2007; Wernig et al., 2007; Ichida et al., 2014).

\section{Selection of Functionally-investigated PATFs C-MYC}

CMYC is part of a family of transcription factors composed of C-MYC, N-MYC, and LMYC (Fagnocchi and Zippo, 2017). The C-MYC gene displays diverse functions in pluripotent cells, such as cell cycle control, cellular metabolism, modulation of signaling pathways, epigenetic control of target genes, and other transcription 
factors, such as HOX genes (Fagnocchi and Zippo, 2017). Both CMYC and NMYC show similar expression patterns during mouse preimplantation development and are functionally redundant for pluripotency (Smith et al., 2010). The expression of CMYC has also been analyzed in preimplantation embryos of ruminants species (Miles et al., 2012; Madeja et al., 2013; Singh et al., 2014; Silva et al., 2017), but its functional roles in such species remain to be described.

\section{Dosage-sensitive sex reversal, adrenal hypoplasia critical region, chromosome $X$, gene 1 (DAX1)}

DAX1 (NR0B1) was detected in oocytes and during all embryonic development of several species (Clipsham et al., 2004; Stickels et al., 2015; Moura et al., 2017; Silva et al., 2017). The characterization of mice lacking DAX1 demonstrated to be dispensable for early embryonic development (Table 1), implantation, and oogenesis (Yu et al., 1998). In contrast, male germ cells do not complete spermatogenesis due to progressive degeneration of the germinative testicular epithelium in mice lacking DAX1 (Yu et al., 1998).

Alternatively, DAX1 contributes to cellular reprogramming by facilitating the reactivation of other pluripotency genes (Zhang et al., 2014; Lujan et al., 2015), although the requirement of its activity to maintain pluripotency remains controversial (Khalfallah et al., 2009; Zhang et al., 2014). The understanding of DAX1 downstream targets in both pluripotent cells and during reprogramming may shed light on how this PATF play such contrasting roles.

\section{Glis family zinc finger 1 (GLIS1)}

GLIS1 was identified in a prospection of transcription factors that are involved in cellular reprogramming (Maekawa et al., 2011). Its expression in mice is enriched in eggs and zygotes, but lower in ES cells, fibroblasts, and other somatic cell types (Maekawa and Yamanaka, 2011). It is possible that GLIS1 was not previously identified as a pluripotency gene since its expression is quite similar between somatic and pluripotent cells (Maekawa and Yamanaka, 2011). In cattle, GLIS1 is more abundant in eggs, embryos up to the fourstage embryo and is barely detected at the eight-cell stage (Takahashi et al., 2015). The knockdown of GLIS1 after fertilization blocks embryonic development at the eight-cell stage, possibly due to a partial or complete block of embryonic genome activation (Takahashi et al., 2015). The genomewide binding profile of GLIS1 in ES cells may be informative about its roles during development and possibly for understanding its contribution to cellular reprogramming.

\section{Kruppel-Like Factor 5 (KLF5)}

KLF5 is part of the Kruppel-like family of transcription factors, composed of 17 members, with diverse activities in several biological processes such as cellular proliferation, metabolism, stress response, among others (Diakiw et al., 2013; Farrugia et al., 2016). KLF5 holds stable expression throughput embryonic development in mice and is required for maintenance of pluripotency (Ema et al., 2008; Parisi and Russo, 2011). The influence of KLF5 on mouse pluripotency depends on the regulation of other pluripotency genes and silencing of genes responsible for cellular differentiation (Parisi and Russo, 2011). The genes KLF2, KLF4, and KLF5 seen to hold redundant activities in mouse ES cells (Jiang et al., 2008). These genes share multiple targeted downstream genes, particularly NANOG, while concomitant silencing of all three genes is required for loss of pluripotency in ES cells (Jiang et al., 2008). Further efforts trying to phenocopy the cellular effects of KLF members in ES cells (i.e., modulation of signaling pathways) should be instructive in understanding their roles in pluripotency and development.

\section{NANOG}

NANOG is another major PATF that controls pluripotency and is required for development (Mitsui et al., 2003). NANOG is a homeodomain protein, with a unique DNA-protein interaction domain and relatively low homology across species (Chambers et al., 2003). In the mouse, NANOG is expressed after embryo compactation and remains restricted to ICMforming cells (Chambers et al., 2003). The expression of NANOG in livestock is found throughout preimplantation development (He et al., 2006; Gossis and Cibelli, 2014). NANOG is required for both ES cell pluripotency in vitro and in vivo (Chambers et al., 2003; Mitsui et al., 2003). NANOG shares hundreds of target genes with OCT4 and SOX2 (Boyer et al., 2005; Loh et al., 2006). However, NANOG should be functionally investigated in greater detail during early development and among species. 


\section{Octamer-binding transcription factor 4 (OCT4)}

The OCT4 gene was the first pluripotencyassociated transcription factor described in early embryos (Schöler et al., 1989, 1990; Rosner et al., 1990) and also the first functionally investigated (Nichols et al., 1998; Niwa et al., 2000; Zeineddine et al., 2014). OCT4 displays expression restricted to germ cells, oocytes, early preimplantation embryos, and ES cells. The silencing of OCT4 causes the formation of blastocysts lacking a pluripotent ICM (Table 1), thus with developmental potential restricted to trophoblastderived lineages (Nichols et al., 1998). Curiously, trophoblast cells require paracrine signaling from pluripotent cells, to retain their bona fide state and viability (Nichols et al., 1998; Le Bin et al., 2014). Although cleavage-stage embryonic development occurs without OCT4, the segregation between epiblast and primitive endoderm is extinguished in ICM cells lacking OCT4 (Le Bin et al., 2014).

The investigation of the OCT4 function at the genomic level has substantially contributed to the understanding of how OCT4 acts upon the control of pluripotency (Boyer et al., 2005; Loh et al., 2006; Zeineddine et al., 2014). OCT4 forms heterodimers with SOX2 and other TFs (Rizzino, 2013), to regulate hundreds of downstream target genes in mouse and human ES cells (Boyer et al., 2005; Loh et al., 2006). The OCT4-SOX2 complex activates other pluripotency genes, controls several signaling pathways, and silences differentiationinducing developmental regulators (Boyer et al., 2005; Rizzino, 2013; Zeineddine et al., 2014). The investigation of OCT4 at the genome-wide level across species should shed light on how this PATF master regulator evolved to contribute to the control of pluripotency.

\section{RONIN (THAP11)}

RONIN was identified as a factor that physically interacts with Caspase 3 in mouse ES cells during differentiation (Dejosez et al., 2008). It was previously demonstrated that NANOG protein cleavage by Caspase 3 was a mechanism for induction of ES cell differentiation (Fujita et al., 2008). In an investigation of proteins that bind to NANOG in ES cells, RONIN (THAP11) was identified as a candidate factor. Curiously, RONIN was dispensable for early embryogenesis, and its target genes were not shared by the core transcriptional circuitry established by OCT4, SOX2, and NANOG (Boyer et al., 2005; Dejosez et al., 2008). This fact suggested that RONIN contributes differently than these other PATFs to the control of pluripotency. A follow-up analysis showed that RONIN participates in the control of cellular processes such as transcription initiation, alternative splicing, and cellular metabolism (Dejosez et al., 2010). The association of RONIN to HCF-1 contributes to ES cells self-renewal and pluripotency by elevating the expression of genes responsible for protein synthesis, and energy production (Dejosez et al., 2010). The molecular circuitry formed by RONIN needs to be further explored to elucidate better how this PATF contribute to pluripotency in embryos and ES cells.

\section{SOX2}

SOX2 is one of the twenty members of the Sry-related HMG box family of transcription factors with various roles during development (Avilion et al., 2003). SOX2 forms a heterodimer with OCT4 and binds to motifs near each other in the genome (Boyer et al., 2005; Rizzino, 2013; Zeineddine et al., 2014). The SOX2 mRNA and protein are detected throughout preimplantation development in several mammalian species and becomes restarted to the ICM (Avilion et al., 2003; Goissis and Cibelli, 2014), but its requirement for development was demonstrated in cattle (Goissis and Cibelli, 2014; Sakurai et al., 2016). The unraveling of SOX2 requirement during preimplantation development of certain species should be an attractive area of investigation.

\section{Zinc Finger Protein 281 (ZFP281)}

ZFP281 (Znf281) was identified as a pluripotency gene due to its differential expression between mouse somatic and ES cells (Wang et al., 2006). More recently, its expression has been described in early embryos of ruminant species (Moura et al., 2017; Silva et al., 2017). The requirement for ZFP281 to maintain pluripotency remains conflicting (Table 1), possibly due to differences in experimental conditions such as gene silencing approach and ES cell culture conditions (Wang et al., 2006; Fidalgo et al., 2011). ZFP281 forms complexes with NANOG, OCT4, and SOX2 in ES cells (Wang et al., 2006, 2008), thus suggesting to be a downstream factor of the OCT4SOX2-NANOG circuitry. Moreover, ZFP281 controls several downstream target genes with the above ciruitry, although its primary role is their expression fine-tuning, including other pluripotency genes (Wang et al., 2008; Fidalgo et al., 2011). Due to this function on other 
pluripotency genes, ZFP281 reduces the efficiency of cellular reprogramming by defined factors through blocking NANOG reactivation (Fidalgo et al., 2012).

\section{Zinc Finger Protein, X-Linked (ZFX)}

The temporal expression of ZFX during embryonic development has been described in several species and was one of the first X-linked genes characterized (Bernardi et al., 1996; Yu et al., 1998; Peippo et al., 2002). ZFX has a homolog on the Y chromosome, denominated ZFY, with stable expression throughout the preimplantation development of male embryos (Bernardi et al., 1996). Moreover, embryos lacking ZFX can reach the blastocyst stage and survive until implantation (Luoh et al., 1997; Galan-Caridad et al., 2007). In contrast, it was demonstrated that ZFX is necessary for both mouse and human pluripotency (GalanCaridad et al., 2007; Harel et al., 2012). It remains an open question why ES cells are dependent on ZFX in contrast to early embryos.

\section{Final Considerations}

Pluripotency has been a focus of intense investigation over the past two decades. Considerable progress has been made toward understanding how a subset of genes, namely pluripotency-associated transcription factors, contribute to the establishment and maintenance of such a cellular state. Due to the intrinsic limitations posed by early preimplantation embryos for experimentation and likely culture-induced effects of ES cell propagation, future investigations should continue to be based on these two systems as converging approaches. Investigations in livestock and other species (aside from mice and humans) should also shed light on how pluripotency is controlled at the molecular level across mammalian species.

\section{References}

Avilion, A.A.; Nicolis, S.K.; Pevny, L.H.; Perez, L.; Vivian, N.; Lovell-Badge, R. Multipotent cell lineages in early mouse development depend on SOX2 function. Genes and Development, 17: 126-140, 2003.

Amit, M.; Carpenter, M.K.; Inokuma, M.S.; Chiu, C.P.; Harris, C.P.; Waknitz, M.A.; ItskovitzEldor, J.; Thomson, J.A. Clonally derived human embryonic stem cell lines maintain pluripotency and proliferative potential for prolonged periods of culture. Developmental Biology, 227: 271-278, 2000.

Barton, L.J.; Leblanc, M.G.; Lehmann, R. Finding their way: themes in germ cell migration. Current Opinion in Cell Biology, 42: 128137, 2016.

Bernardi, M.L; Cotinot, C.; Payen, E.; Delouis, C. Transcription of $\mathrm{Y}$ - and $\mathrm{X}$-Linked Genes in Preimplantation Ovine Embryos. Molecular Reproduction and Development, 45: 132138, 1996.

Boyer, L.A., Lee, T.I., Cole, M.F., Johnstone, S.E., Levine, S.S., Zucker, J.P., Guenther, M.G., Kumar, R.M., Murray, H.L., Jenner, R.G., Gifford, D.K., Melton, D.A., Jaenisch, R., Young, R.A. Core transcriptional regulatory circuitry in human embryonic stem cells. Cell, 122: 947-956, 2005.

Bradley, A.; Evans M.; Kaufman, M.H; Robertson, E. Formation of germ-line chimaeras from embryo-derived teratocarcinoma cell lines. Nature, 309: 255256, 1984.

Buehr, M.; Meek, S.; Blair, K.; Yang, J.; Ure, J.; Silva, J.; Mclay, R.; Hall, J.; Ying, Q.L.; Smith, A. Capture of authentic embryonic stem cells from rat blastocysts. Cell, 135: 1287-1298, 2008.

Capecchi, M.R. Altering the genome by homologous recombination. Science, 244: 1288-1292, 1989.

Capecchi, M.R. Gene targeting in mice: functional analysis of the mammalian genome for the twenty-first century. Nature Reviews Genetics, 6: 507-512, 2005.

Chambers, I.; Colby, D.; Robertson, M.; Nichols, J.; Lee, S.; Tweedie, S.; Smith, A. Functional expression cloning of Nanog, a pluripotency sustaining factor in embryonic stem cells. Cell, 113: 643-655, 2003.

Chen, X.; Ye, S.; Ying, Q.L. Stem cell maintenance by manipulating signaling pathways: past, current and future. BMB Reports, 48(12): 668- 676, 2015.

Clipsham, R.; Niakan, K.; Mccabe, E.R. NR0B1 and its network partners are expressed early in murine embryos prior to steroidogenic axis organogenesis. Gene Expression Patterns, 4: 3-14, 2004.

Cockburn, K.; Rossant, J. Making the blastocyst: lessons from the mouse. Journal of Clinical Investigation, 120: 995-1003, 2010. 
Diakiw, S.M.; D'Andrea, R.J.; Brown, A.L. The double life of KLF5: Opposing roles in regulation of gene-expression, cellular function, and transformation. IUBMB Life, 65: 999-1011, 2013.

Dejosez, M.; Krumenacker, J.S.; Zitur, L.J.; Passeri, M.; Chu, L.F.; Songyang, Z.; Thomson, J.A.; Zwaka, T.P. Ronin is essential for embryogenesis and the pluripotency of mouse embryonic stem cells. Cell, 133: 1162-1174, 2008.

Dejosez, M.; Levine, S.S.; Frampton, G.M.; Whyte, W.A.; Stratton, S.A.; Barton, M.C.; Gunaratne, P.H.; Young, R.A.; Zwaka, T.P. Ronin/Hcf-1 binds to a hyperconserved enhancer element and regulates genes involved in the growth of embryonic stem cells. Genes and Development, 24: 14791484, 2010.

Ema, M.; Mori, D.; Niwa, H.; Hasegawa, Y.; Yamanaka, Y.; Hitoshi, S.; Mimura, J.; Kawabe, Y.; Hosoya, T.; Morita, M.; Shimosato, D.; Uchida, K.; Suzuki, N.; Yanagisawa, J.; Sogawa, K.; Rossant, J.; Yamamoto, M.; Takahashi, S.; FujiiKuriyama, Y. Krüppel-like factor 5 is essential for blastocyst development and the normal self-renewal of mouse ESCs. Cell Stem Cell, 3: 555-567, 2008.

Evans, M.J.; Kaufman, M.H. Establishment in culture of pluripotential cells from mouse embryos. Nature, 292: 154-156, 1981.

Fagnocchi, L.; Zippo, A. Multiple Roles of MYC in Integrating Regulatory Networks of Pluripotent Stem Cells. Frontiers in Cell and Developmental Biology, 5: 7, 2017.

Farrugia, M.K.; Vanderbilt, D.B.; Salkeni, M.A.; Ruppert, J.M. Kruppel-like Pluripotency Factors as Modulators of Cancer Cell Therapeutic Responses. Cancer Research, 76: 1677-1682, 2016.

Fidalgo, M.; Shekar, P.C.; Ang, Y.S.; Fujiwara, Y.; Orkin, S.H.; Wang, J. Zfp281 functions as a transcriptional repressor for pluripotency of mouse embryonic stem cells. Stem Cells, 29: 1705-1716, 2011.

Fidalgo, M.; Faiola, F.; Pereira, C.F.; Ding, J.; Saunders, A.; Gingold, J.; Schaniel, C.; Lemischka, I.R.; Silva, J.C.; Wang, J. ZFP281 mediates NANOG autorepression through recruitment of the NuRD complex and inhibits somatic cell reprogramming.
Proceedings of the National Academy of Sciences, 40: 16202-16207, 2012.

Fogarty NME, McCarthy A, Snijders KE, Powell BE, Kubikova N, Blakeley P, Lea R, Elder K, Wamaitha SE, Kim D, Maciulyte V, Kleinjung J, Kim JS, Wells D, Vallier L, Bertero A, Turner JMA, Niakan KK. Nature, v.550, n.7674, p. 67-73, 2017.

Frankenberg, S.R.; De Barros, F.R.; Rossant, J.; Renfree, M.B. The mammalian blastocyst. Wiley Interdisciplinary Reviews. Developmental Biology, 5: 210-232, 2016.

Fujita, J.; Crane, A.M.; Souza M.K.; Dejosez, M.; Kyba, M.; Flavell, R.A.; Thomson, J.A.; Zwaka, T.P. Cell Stem Cell, 2: 595-601, 2008.

Galan-Caridad, J.M.; Harel, S.; Arenzana, T.L.; Hou, Z.E.; Doestsch, F.K.; Mirny, L.A.; Reizis, B. Zfx controls the self-renewal of embryonic and hematopoietic stem cells. Cell, 129: 345-357, 2007.

Goissis, M.D.; Cibelli, J.B. Functional characterization of SOX2 in bovine preimplantation embryos. Biology of Reproduction, 90(30): 2014.

Gurdon, J.B. From nuclear transfer to nuclear reprogramming: the reversal of cell differentiation. Annual Review of Cell and Developmental Biology, 22: 1-22, 2006.

Harel, S.; Tu, E.Y.; Weisberg, S.; Esquilin, M.; Chambers, S.M.; Liu, B.; Carson, C.T.; Studer, L.; Reizis, B.; Tomishima, M.J. ZFX controls the self-renewal of human embryonic stem cells. PLoS One, 7: e42302, 2012.

He, S.; Pant, D.; Schiffmacher, A.; Bischoff, S.; Melican, D.; Gavin, W.; Keefer, C. Developmental expression of pluripotency determining factors in caprine embryos: novel pattern of NANOG protein localization in the nucleolus. Molecular Reproduction and Development, 73(12): 1512-1522, 2006.

Heng, J.C., Orlov, Y.L., Ng, H.H. Transcription actors for the Modulation of Pluripotency and Reprogramming. Cold Spring Harbor Symposium on Quantative Biology, 75: 237- 244, 2010.

Hochedlinger, K.; Jaenisch, R. Nuclear reprogramming and pluripotency. Nature, 441: 1061-1067, 2006.

Ichida, J.K.; Tcw, J.; Williams, L.A.; Carter, A.C.; Shi, Y.; Moura, M.T.; Ziller, M.; SINGH, S.; 
Amabile, G.; Bock, C.; Umezawa, A.; Rubin, L.L.; Bradner, J.E.; Akutsu, H.; Meissner, A.; Eggan, K. Notch inhibition allows oncogeneindependent generation of iPS cells. Nature Chemical Biology, 10: 632-639, 2014.

Jiang, J.; Chan, Y.S.; Loh, Y.H.; Cai, J.; Tong, G.Q.; Lim, C.A.; Robson, P.; Zhong, S.; Ng, H.H. A core KLF circuitry regulates selfrenewal of embryonic stem cells. Nature Cell Biology, 10: 353-360, 2008.

Khalfallah, O.; Rouleau, M.; Barbry, P.; Bardoni, B.; Lalli, E. DAX-1 knockdown in mouse embryonic stem cells induces loss of pluripotency and multilineage differentiation. Stem Cells, 27: 1529-1537, 2009.

Kim, J.; Chu, J.; Shen, X.; Wang, J.; Orkin, S.H. An extended transcriptional network for pluripotency of embryonic stem cells. Cell, 132: 1049-1061, 2008.

Kwon, J.; Namgoong, S.; Kim, N.H. CRISPR/Cas 9 as tool for functional study of genes involved in preimplantation embryo development. PLoS One, 10(3): e0120501, 2015.

Latham, K.E. Mechanisms and control of embryonic genome activation in mammalian embryos. International Review of Cytology, 193: 71-124, 1999.

Le Bin, G.C.; Muñoz-Descalzo, S.; Kurowski, A.; Leitch, H.; Lou, X.; Mansfield, W.; EtienneDumeau, C.; Grabole, N.; Mulas, C.; Niwa, H.; Hadjantonakis, A.K.; Nichols, J. OCT4 is required for lineage priming in the developing inner cell mass of the mouse blastocyst. Development, 141: 1001-1010, 2014.

Li, P.; Tong, C.; Mehrian-Shai, R.; Jia, L.; Wu, N.; Yan, Y.; Maxson, R.E.; Schulze, E.N.; Song, H.; Hsieh, C.L.; Pera, M.F.; Ying, Q.L. Germline competent embryonic stem cells derived from rat blastocysts. Cell, 135: 12991310, 2008.

Li, M.; Belmonte, J.C. Ground rules of the pluripotency gene regulatory network. Nature Reviews Genetics, 18: 180-191, 2017.

Loh, Y.H.; Wu, Q.; Chew, J.L.; Vega, V.B.; Zhang, W.; Chen, X.; Bourque, G.; George, J.; Leong, B.; Liu, J.; Wong, K.Y.; Sung, K.W.; Lee, C.W.; Zhao, X.D.; Chiu, K.P.; Lipovich, L.; Kuznetsov, V.A.; Robson, P.; Stanton, L.W.; Wei, C.L.; Ruan, Y.; Lim, B.;
Ng, H.H. The Oct4 and Nanog transcription network regulates pluripotency in mouse embryonic stem cells. Nature Genetics, 38: 431-440, 2006.

Lujan, E.; Zunder, E.R.; Ng, Y.H.; Goronzy, I.N.; Nolan, G.P.; Wernig, M. Early reprogramming regulators identified by prospective isolation and mass cytometry. Nature, 521: 352-356, 2015.

Luoh, S.W.; Bain, P.A.; Polakiewicz, R.D.; Goodheart, M.L.; Gardner, H.; Jaenisch, R.; Page D.C. ZFX mutation results in small animal size and reduced germ cell number in male and female mice. Development, 124: 2275-2284, 1997.

Madeja, Z. E.; Sosnowski, J.; Hryniewicz, K.; Warzych, E.; Pawlak, P.; Rozwadowska, N.; Plusa, B.; Lechniak, D. Changes in subcellular localisation of trophoblast and inner cell mass specific transcription factors during bovine preimplantation development. BMC Developmental Biology, 13: 32, 2013.

Maekawa, M.; Yamaguchi, K.; Nakamura, T.; Shibukawa, R.; Kodanaka, I. Ichisaka, T.; Kawamura, Y.; Mochizuki, H.; Goshima, N.; Yamanaka, S. Direct reprogramming of somatic cells is promoted by maternal transcription factor GLIS1. Nature, 474: 225-229, 2011.

Maekawa, M.; Yamanaka, S. GLIS1, a unique pro-reprogramming factor, may facilitate clinical applications of iPSC technology. Cell Cycle, 10: 3613-3614, 2011.

Maherali, N.; Sridharan, R.; Xie, W.; Utikal, J.; Eminli, S.; Arnold, K.; Stadtfeld, M.; Yachechko, R.; Tchieu, J.; Jaenisch, R.; Plath, K.; Hochedlinger, K. Directly reprogrammed fibroblasts show global epigenetic remodeling and widespread tissue contribution. Cell Stem Cell, 1: 55-70, 2007.

McLaren, A. Germ and somatic cell lineages in the developing gonad. Molecular and Cellular Endocrinology, 163: 3-9, 2000.

Memili, E.; First, N.L. Zygotic and embryonic gene expression in cow: a review of timing and mechanisms of early gene expression as compared with other species. Zygote, 8: 8796, 2000.

Miles, J.R.; McDaneld, T.G.; Wiedmann, R.T.; Cushman, R.A.; Echternkamp, S.E.; Vallet, J.L.; Smith, T.P. MicroRNA expression profile in bovine cumulus-oocyte complexes: 
possible role of let-7 and miR-106a in the development of bovine oocytes. Animal Reproduction Science, 130: 16-26, 2012.

Mitsui, K.; Tokuzawa, Y.; Itoh, H.; Segawa, K.; Murakami, M.; Takahashi, K.; Maruyama, M.; Maeda, M.; Yamanaka, S. The homeoprotein Nanog is required for maintenance of pluripotency in mouse epiblast and ES cells. Cell, 113: 631-642, 2003.

Moore, N.W.; Adams, C.E.; Rowson, L.E. Developmental potential of single blastomeres of the rabbit egg. Journal of reproduction and fertility, 17: 527- 531, 1968.

Moura, M.T. Pluripotency and cellular reprogramming. Anais da Academia Pernambucana de Ciência Agronômica, 8: 138-168, 2012.

Moura, M.T.; Ramos-Deus, P.; Ferreira-Silva, J.C.; Silva, P.G.C.; Cantanhêde, L.F.; Nascimento, P.S.; Silva, R.L.O.; BenkoIseppon, A.M.; Oliveira, M.A.L. Expression of RONIN and NANOG-associated proteins in goat parthenogenetic embryos. Medicina Veterinária (UFRPE), 11(2): 145-152, 2017.

Nagy, A.; Gócza, E.; Diaz, E.M.; Prideaux, V.R.; Iványi, E.; Markkula, M.; Rossant, J. Embryonic stem cells alone are able to support fetal development in the mouse. Development, 110: 815-821, 1990.

Niakan, K.K.; Davis, E.C.; Clipsham, R.C.; Jiang, M.; Dehart, D.B.; Sulik, K.K.; McCabe, E.R. Novel role for the orphan nuclear receptor Dax1 in embryogenesis, different from steroidogenesis. Molecular Genetics and Metabolism, 88: 261-271, 2006.

Nichols, J.; Zevnik, B.; Anastassiadis, K.; Niwa, H.; Klewe-Nebenius, D.; Chambers, J.; Schöler, H.; Smith, A. Formation of pluripotent stem cells in the mammalian embryo depends on the POU transcription factor Oct4. Cell, 95: 379-391, 1998.

Niwa, H.; Miyazaki, J.; Smith, A.G. Quantitative expression of Oct-3/4 defines differentiation, dedifferentiation or self-renewal of ES cells. Nature Genetics, 24: 372- 376, 2000.

Okita, K.; Ichisaka, T.; Yamanaka, S. Generation of germline-competent induced pluripotent stem cells. Nature, 448: 313-317, 2007.

Parisi, S.; Russo, T. Regulatory role of KLF5 in early mouse development and in embryonic stem cells. Vitamins and Hormones, 87: 381-397, 2011.

Peippo, J.; Farazmand, A.; Kurkilahti, M.; Markkula, M.; Basrur, P.K.; King, W.A. Sexchromosome linked gene expression in-vitro produced bovine embryos. Molecular Human Reproduction, 8: 923-929, 2002.

Picard, L.; Chartrain, I.; King, W.A.; Betteridge, K.J. Production of chimaeric bovine embryos and calves by aggregation of inner cell masses with morulae. Molecular Reproduction and Development, 27: 295304, 1990.

Rizzino, A. Concise review: The Sox2-Oct4 connection: critical players in a much larger interdependent network integrated at multiple levels. Stem Cells, 31: 1033-1039, 2013.

Rosner, M.H.; Vigano, M.A.; Ozato, K.; Timmons, P.M.; Poirier, F.; Rigby, P.W.; Staudt, L.M. A POU-domain transcription factor in early stem cells and germ cells of the mammalian embryo. Nature, 345: 686-692, 1990.

Rossant, J. Stem cells and lineage development in the mammalian blastocyst. Reproduction, Fertility and Development, 19: 111-118, 2007.

Rossant, J. Making the Mouse Blastocyst: Past, Present, and Future. Current Topics in Developmental Biology, 117: 275-288, 2016.

Sakurai, N.; Takahashi, K.; Emura, N.; Fujii, T.; Hirayama, H.; Kageyama, S.; Hashizume, T.; Sawai, K. The Necessity of OCT-4 and CDX2 for Early Development and Gene Expression Involved in Differentiation of Inner Cell Mass and Trophectoderm Lineages in Bovine Embryos. Cellular Reprogramming, 18: 309-318, 2016.

Schöler, H.R.; Hatzopoulos, A.K.; Balling, R.; Suzuki, N.; Gruss, P. A family of octamerspecific proteins present during mouse embryogenesis: evidence for germlinespecific expression of an Oct factor. EMBO Journal, 8: 2543-2550, 1989.

Schöler, H.R.; Ruppert, S.; Suzuki, N.; Chowdhury, K.; Gruss, P. New type of POU domain in germ line-specific protein Oct-4. Nature, 344: 435-439, 1990.

Scognamiglio, R.; Cabezas-Wallscheid, N.; Thier, M.C.; Altamura, S.; Reyes, A.; Prendergast, Á.M.; Baumgärtner, D.; Carnevalli, L.S.; Atzberger, A.; Haas, S.; Von paleske, L.; 
Boroviak, T.; Wörsdörfer, P.; Essers, M.A.; Kloz, U.; Eisenman, R.N.; Edenhofer, F.; Bertone, P.; Huber, W.; Van Der Hoeven, F.; Smith, A.; Trumpp, A. Myc Depletion Induces a Pluripotent Dormant State Mimicking Diapause. Cell, 164: 668-680, 2016.

Silva, P.G.C.; Moura, M.T.; Braga, V.A.A.; Ferreira-Silva, J.C.; Nascimento, P.S.; Cantanhêde, L.F.; Chaves, M.S.; Oliveira, M.A.L. 2017. Atividade dos genes relacionados à pluripotência em ovinos. Medicina Veterinária (UFRPE), 11(2): 127-136, 2017.

Singh, K.P.; Kaushik, R.; Mohapatra, S.K.; Garg, V.; Rameshbabu, K.; Singh, M.K.; Palta, P.; Manik, R.S.; Singla, S.K.; Chauhan, M.S. Quantitative expression of pluripotencyrelated genes in parthenogenetically produced buffalo (Bubalus bubalis) embryos and in putative embryonic stem cells derived from them. Gene Expression Patterns, 16: 23-30, 2014.

Smith, A.G. Embryo-derived stem cells: of mice and men. Annual Review of Cell and Developmental Biology, 17: 435-462, 2001.

Smith, K.N.; Singh, A.M.; Dalton, S. CMyc represses primitive endoderm differentiation in pluripotent stem cells. Cell Stem Cell, 7: 343-354, 2010.

Stickels, R.; Clark, K.; Heider, T.N.; Mattiske, D.M.; Renfree, M.B.; Pask, A.J. DAX1/NR0B1 was expressed during mammalian gonadal development and gametogenesis before it was recruited to the eutherian $\mathrm{X}$ chromosome. Biology of Reproduction, 92: 22, 2015.

Subramanian, V.; Klattenhoff, C.A.; Boyer, L.A. Screening for novel regulators of embryonic stem cell identity. Cell Stem Cell, 4: 377378, 2009.

Tagarelli, A.; Piro, A.; Lagonia, P.; Tagarelli, G. Hans Spemann. One hundred years before the birth of experimental embryology. Anatomia, Histologia, Embryologia, 33: 28-32, 2004.

Takahashi, K.; Yamanaka, S. Induction of pluripotent stem cells from mouse embryonic and adult fibroblast cultures by defined factors. Cell, 126: 663-676. 2006.

Takahashi, K.; Tanabe, K.; Ohnuki, M.; Narita, M.; Ichisaka, T.; Tomoda, K.; Yamanaka, S. Induction of pluripotent stem cells from adult human fibroblasts by defined factors. Cell, 131: 861-872, 2007.

Takahashi, K.; Sakurai, N.; Emura, N.; Hashizume, T.; Sawai, K. Effects of downregulating GLIS1 transcript on preimplantation development and gene expression of bovine embryos. Journal Reproduction and Development, 61: 369374, 2015.

Takahashi, K.; Yamanaka, S. A decade of transcription factor-mediated reprogramming to pluripotency. Nature Reviews Molecular Cell Biology, 17: 183-193, 2016.

Wang, J.; Rao, S.; Chu, J.; Shen, X.; Levasseur, D.N.; Theunissen, T.W.; Orkin, S.H. A protein interaction network for pluripotency of embryonic stem cells. Nature, 444: $364-$ 368, 2006.

Wang, Z.X.; The, C.H.; Chan, C.M.; Chu, C.; Rossbach, M.; Kunarso, G.; Allapitchay, T.B.; Wong, K.Y.; Stanton, L.W. The transcription factor ZFP281 controls embryonic stem cell pluripotency by direct activation and repression of target genes. Stem Cells, 26: 2791-2799, 2008.

Wernig, M.; Meissner, A.; Foreman, R.; Brambrink, T.; Ku, M.; Hochedlinger, K.; Bernstein, B.E.; Jaenisch, R. In vitro reprogramming of fibroblasts into a pluripotent ES-cell-like state. Nature, 448: 318-324, 2007.

Willadsen, S.M. The development capacity of blastomeres from 4- and 8-cell sheep embryos.. Journal of embryology and experimental morphology, 1981.

Wu, G.; Lei, L.; Schöler, H.R. Totipotency in the mouse. J Mol Med (Berl), 95: 687-694, 2017.

Yeo, J.C.; Ng, H.H. The transcriptional regulation of pluripotency. Cell Research, 23: 20-32, 2013.

Young, R.A. Control of the embryonic stem cell state. Cell, 144: 940-954, 2011.

Yu, R.N.; Ito, M.; Saunders, T.L.; Camper, S.A.; Jameson, J.L. Role of Ahch in gonadal development and gametogenesis. Nature Genetics, 20: 353-357, 1998.

Zeineddine, D.; Hammoud, A.A.; Mortada, M.; Boeuf, H.; Am, J. The Oct4 protein: more than a magic stemness marker. Stem Cells, 3: 74-82, 2014.

Zhang, J.; Liu, G.; Ruan, Y.; Wang, J.; Zhao, K.; Wan, Y.; Liu, B.; Zheng, H.; Peng, T.; Wu, 
W.; He, P.; Hu, F.Q.; Jian, R. DAX1 and NANOG act in parallel to stabilize mouse embryonic stem cells and induced pluripotency. Nature Communications, 5: 5042, 2014.
Zheng, X.; Hu, G. Use of genome-wide RNAi screens to identify regulators of embryonic stem cell pluripotency and self-renewal. Methods in Molecular Biology, 1150: 163$173,2014 .$. 